\title{
МЕЗЕНХИМНЫЕ СТВОЛОВЫЕ КЛЕТКИ ИЗ ЖИРОВОЙ ТКАНИ КОШЕК И СОБАК В КУЛЬТУРЕ*
}

\section{И.П. САВЧЕНКОВА, С.А. ВАСИЛЬЕВА, Д.Г. КОРОВИНА, А.А. ШАБЕЙКИН, А.М. ГУЛЮКИН}

Мультипотентные мезенхимные стволовые клетки (ММСК) рассматриваются как перспективный инструмент регенеративной медицины для лечения различных заболеваний мелких домашних животных. ММСК обладают высокой пролиферативной активностью, мультипотентными свойствами, низкой иммуногенностью, а также способностью мигрировать к поврежденной ткани и содействовать ее заживлению и регенерации. В настоящее время активно развиваются методы регенеративной медицины для решения проблем, с которыми трудно справиться альтернативными способами лечения. Однако данные о применении ММСК в клинической практике опережают работы по изучению свойств этих клеток в культуре. В связи с этим нами из внутренней жировой ткани (ЖТ) кошек и собак выделены клетки с фенотипом, подобным ММСК млекопитающих. Цель исследования, представленного в этом сообщении, заключалась в изучении культуральных свойств впервые выделенных клеток in vitro. Клетки выделяли посредством последовательной механической и ферментативной обработки жиров. Для ферментативной диссоциации ткани использовали 0,01 \% раствор коллагеназы II типа на основе среды DMEM-LG («ПанЭко», Россия) с низким содержанием глюкозы (1 г/л) при $37^{\circ} \mathrm{C}$ в течение 60 мин. Сравнительный анализ свойств полученных клеточных популяций выявил, что клетки, выделенные из ЖТ кошек и собак, имели схожие морфологические характеристики и представляли собой два типа клеток: мелкие округлые клетки и более крупные узкие веретенообразные с фибробластоподобной морфологией. Обе популяции проявляли способность к сильной адгезии к культуральному

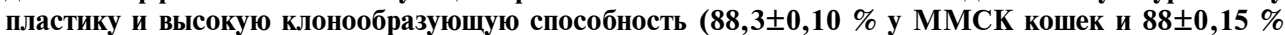
у ММСК собак). Время одной цитогенерации у ММСК кошек составило 34,6 $\pm 0,02$ ч, у собак $50,0 \pm 0,01$ ч. Митотический индекс ММСК ЖТ кошки и ММСК ЖТ собаки - соответственно 3,4 и 2,7 \%о. Способность ММСК кошки и собаки к индукционной остео-, хондро- и адипогенной дифференцировке in vitro изучали с использованием наборов StemPro® Osteogenesis Differentiation Kit, StemPro ${ }^{\circledR}$ Chondrogenesis Differentiation Kit и StemPro ${ }^{\circledR}$ Adipogenesis Differentiation Kit («Gibco», CША). Адипогенная дифференцировка сопровождалась появлением клеток округлой формы с липидными везикулами в цитоплазме, которые выявлялись при окрашивании жировым красным О. Окрашивание ММСК ЖТ кошки и собаки на специфическую активность эндогенной щелочной фосфатазы оказалось положительным на 14-е сут культивирования в индукционной среде. Окрашивание ММСК ЖТ серебрением по von Коssа выявило в клетках секрецию внеклеточного матрикса в виде фосфатов и карбонатов на 21-е сут после индукции. После культивирования клеток, выделенных из ЖТ кошек и собак, в хондрогенной среде в течение 21 сут было обнаружено формирование круглых структур, которые окрашивались альциановым синим, с визуализируемыми изогенными группами, схожими с лакунами гиалинового хряща. Таким образом, было показано, что клетки, выделенные из ЖТ кошек и собак, проявляют в культуре свойства ММСК. Полученные культуры клеток были размножены и депонированы в Специализированную Коллекцию перевиваемых соматических клеточных культур сельскохозяйственных и промысловых животных при ВИЭВ им. Я.Р. Коваленко (СХЖ РАСХН).

Ключевые слова: мультипотентные мезенхимные стволовые клетки, жировая ткань, культивирование, индукция, дифференцировка in vitro, кошка, собака.

Развитие методов получения из тканей животных столовых клеток без нанесения ущерба здоровью, их культивирования и хранения способствовало широкому применению таких клеток в различных научных областях. Культуры клеток как лабораторные модели давно применяются в изучении биологии клетки, генетике, токсикологии, вирусологии, медицине и биотехнологии. В ветеринарной вирусологии культуры клеток используются в изучении репродукции вирусов, в диагностических исследованиях, при производстве разнообразных противовирусных препаратов. Для этих целей часто применяют диплоидные культуры клеток, выделенные из тканей и органов животных и их плодов. Диплоидные культуры клеток имеют ряд недостатков, в том

\footnotetext{
* Работа выполнялась в рамках НИР № 0578-2018-0006 «Создание новых клеточных систем с заданными свойствами на основе стволовых клеток млекопитающих, в том числе сельскохозяйственных животных для ветеринарии, вирусологии и биотехнологии».
} 
числе отсутствие стандартизации и краткосрочность культивирования (до 50 цитогенераций). Перевиваемые иммортализованные (бессмертные) клеточные линии в этом отношении наиболее перспективны. Однако их применение сдерживается потерей тканевой принадлежности в результате длительного культивирования, что приводит к ослаблению вирулентности вирусов. Кроме того, перевиваемые клетки, выделенные из тканей сельскохозяйственных животных, часто контаминированы вирусами. В связи с этим мультипотентные мезенхимные стволовые клетки (ММСК) животных могут рассматриваться в качестве новой клеточной модели, которая имеет ряд преимуществ перед диплоидными и перевиваемыми культурами клеток.

С MMCK млекопитающих связывают перспективы решения многих ветеринарных, медицинских и биотехнологических проблем. У человека ММСК обнаружены в костном мозге (КМ), жировой ткани (ЖТ), скелетных мышцах, плаценте, пуповинной крови и других тканях (1). ММСК обладают уникальными свойствами. Они способны длительное время сохранять геномную стабильность при самообновлении (более 50-55 цитогенераций) in vitro, а также могут формировать in vitro клетки костной, хрящевой и жировой тканей при индукции к дифференцировке (2). Ранее нами были выделены ММСК из пуповинной крови лошадей (3), КМ и ЖТ крупного рогатого скота (4). Показана возможность использования ММСК, выделенных из ПК лошадей, для изучения вируса инфекционной анемии лошадей (3). Необходимость получения культур ММСК мелких домашних животных обусловлена, в частности, их перспективностью для биотехнологии производства противовирусных препаратов плотоядных, в том числе вакцин против парвовирусных энтеритов собак, норок, кошек, лисиц, чумы плотоядных и, конечно, бешенства.

В настоящее время изучению биологии ММСК человека in vitro уделяется большое внимание, при этом ММСК рассматривают как биомедицинский клеточный продукт (Федеральный закон № 180-Ф3 от 23 июня 2016 г. «О биомедицинских клеточных продуктах»). Считается, что в клеточной терапии ММСК проявляют себя как иммуносупрессоры (5). Анализ опубликованных источников показал, что аналогичные исследования ведутся на мелких домашних животных - кошках (6-9) и собаках $(10,11)$. ММСК - перспективный клеточный материалом для лечения патологий костной и хрящевой ткани, в том числе остеоартритов и межпозвоночных грыж у кошек и собак (12-14). Для этих целей требуется большое количество клеток, которые получают переводом их в культуру. Поиск оптимальных условий культивирования для эффективного наращивания клеточной массы имеет первостепенное значение. Следует констатировать, что в настоящее время практическое применение ММСК, к сожалению, опережает работы по их изучению в культуре. В связи с этим необходимо исследовать свойства этих клеток вне ткани или органа, из которого они были выделены. Доклинические исследования биомедицинских клеточных продуктов проводятся с использованием лабораторных животных (мыши, крысы), что часто затрудняет интерпретацию полученных результатов. Кошки и собаки могут оказаться более подходящими моделями для подобных целей, и получение ММСК этих видов животных может решить вопрос наличия контроля для проведения доклинических исследований. Выделение, изучение свойств ММСК различных видов в культуре, согласно общепринятым требованиям, предъявляемым для этого типа клеток у человека, позволяет создавать крупные банки и национальные коллекции аттестованных клеточных культур стволовых клеток.

В представленной работе мы выделили клетки жировой ткани кошек и собак, обладающие всеми главными признаками мультипотентных 
мезенхимных стволовых клеток, и получили их культуры. При химической индукции эти клетки дифференцируются по остео-, хондро- и адипогенному типу. Показано, что более высокой пролиферативной активностью обладают культуры ММСК кошек.

Нашей целью было выделение из жировой ткани кошек и собак in vitro клеток, подобных по фенотипу мультипотентным мезенхимным стволовым клеткам, и изучение их свойств в культуре.

Методика. ЖТ получали от кошек в возрасте 8 мес и собак в возрасте 1 года (по три особи) в ветеринарной клинике ФГБНУ ФНЦ ВИЭВ им. Я.Р. Коваленко при овариоэктомии, которую проводили в соответствии с Хельсинской декларацией (World Medical Association Declaration of Helsinki: ethical principles for medical research involving human subjects, 19642013). Время транспортировки образцов в лабораторию составило менее 30 мин. Клетки выделяли по методике, описанной нами ранее (16). Полученный образец внутренней ЖТ (2-4 г) тщательно промывали PBS («ПанЭко», Россия) без ионов $\mathrm{Ca}^{2+}$ и $\mathrm{Mg}^{2+}$, измельчали и подвергали ферментативной обработке $0,01 \%$ раствором коллагеназы II типа, приготовленным на основе DMEM LG («ПанЭко», Россия) с низким содержанием глюкозы (1 г/л), в течение 60 мин при $37^{\circ} \mathrm{C}$. Действие коллагеназы нейтрализовали равным объемом питательной среды DMEM LG, дополненной 10 \% сыворотки крови плодов коров (СКПК), и центрифугировали при $1000 \mathrm{~g}$ в течение 10 мин. Клетки дважды промывали в среде ДМЕM LG с антибиотиками (конечная концентрация стрептомицина 50 мкг/мл, пенициллина 50 ЕД/мл) и осаждали центрифугированием при 800 g в течение 10 мин.

После завершающего осаждения к клеточному осадку добавляли DMEM LG, тщательно ресуспендировали и поэтапно фильтровали через сеточки для клеток («SPL Life Sciences Co., Ltd.», Корея). На первом этапе отбирали клетки стромально-васкулярной фракции (СВФ) с помощью сеточек с размером пор 70 мкм, затем для селекции стволовых клеток пропускали полученную СВФ через фильтры с размером пор 10 мкм.

После подсчета в камере Горяева клетки $\left(1,2 \times 10^{6}\right)$ помещали в культуральный флакон (площадь поверхности роста $25 \mathrm{~cm}^{2}$ ). Основной ростовой средой для культивирования ММСK была DMEM LG с 10 \% СКПК (НуClone, «Perbio Scientific», Бельгия) и антибиотиками (конечная концентрация стрептомицина 50 мкг/мл, пенициллина - 50 ЕД/мл). Через 24 ч ростовую среду заменяли на свежую, а прикрепившиеся клетки оставляли на доращивание в $\mathrm{CO}_{2}$-инкубаторе $\left(5 \% \mathrm{CO}_{2}, 37^{\circ} \mathrm{C}\right)$.

Продолжительность клеточного цикла в исследуемых ММСК определяли на основании данных о времени удвоения числа клеток. Долю клеток в фазе $\mathrm{G}_{0}$ не учитывали. Скорость роста клеточных популяций анализировали по динамике изменения числа клеток вплоть до момента образования монослоя. Среднее время удвоения числа клеток рассчитывали по формуле: $t_{d}=t / \log _{2}\left(N_{t} / N_{0}\right)$, где $t_{d}-$ время удвоения числа клеток, $t-$ время между начальным и конечным подсчетом клеток, $N_{o}$ и $N_{t}$ - число клеток соответственно в начале и конце эксперимента (17). Митотический индекс для каждой популяции клеток рассчитывали в фазу логарифмического роста как отношение числа митозов к общему числу подсчитанных клеток, умноженное на 1000 (\%о).

Морфологию клеток (нативных и окрашенных по РомановскомуГимзе) оценивали визуально (инвертированный фазово-контрастный микроскоп Axio Observer D.1, «Carl Zeiss», Германия, увеличение ×100, ×200, ×630; программное обеспечение AxioVision Rel. 4.8, разработанное той же фирмой).

Эффективность клонообразования оценивали при посеве клеток 
$\left(1,5 \times 10^{3}\right)$ в культуральные флаконы $\left(25 \mathrm{~cm}^{2}\right)$ и рассчитывали как отношение общего числа внесенных клеток к числу клонов, образовавшихся на 10-е сут культивирования.

Способность ММСК кошек и собак к индукционной дифференцировке in vitro соответственно в остео-, хондро- и адипогенном направлениях изучали с использованием наборов StemPro® Osteogenesis Differentiation Kit, StemPro ${ }^{\circledR}$ Chondrogenesis Differentiation Kit и StemPro ${ }^{\circledR}$ Adipogenesis Differentiation Kit («Gibco», США). Для этого MMCK на 2-3-м пассажах высевали в 12-луночные планшеты («SPL Life Sciences Co., Ltd.», Корея) $\left(1 \times 10^{5}\right.$ клеток на лунку). По достижении клетками 70-80 \% монослоя рабочую питательную среду удаляли и добавляли индукционные среды в соответствии с рекомендации производителя. Индукционные среды меняли каждые 4 сут в течение 21 сут. Дифференцировку ММСК кошек и собак оценивали на 14-е и 21-е сут. Для этого клетки фиксировали ледяным метанолом $\left(-20{ }^{\circ} \mathrm{C}\right)$ в течение 10 мин и окрашивали специфическими красителями (все красители фирмы «Sigma-Aldrich», США). Щелочную фосфатазу (ЩФ) в клетках выявляли с помощью набора Alkaline Phosphatase Kit («Sigma-Aldrich», США). Для выявления фосфатов и карбонатов при остеогенной дифференцировке MMCK клетки окрашивали методом серебрения по von Kossa согласно инструкциям производителя реактивов. При серебрении клетки после фиксации обрабатывали $2 \%$ водным раствором $\mathrm{AgNO}_{3}$ в течение 10-15 мин и помещали под прямые лучи лампы $(60$ Вт) на 1 ч, затем промывали дистиллированной водой и обрабатывали 2,5 \% водным раствором тиосульфата натрия в течение 1 мин, промывали водопроводной водой и изучали под микроскопом (Axio Observer D.1, «Carl Zeiss», Германия, увеличение $\times 100, \times 200, \times 630)$. Для оценки хондрогенной дифференцировки ММСК использовали краситель альциновый синий («ЛабПоинт», Россия), который окрашивает мукополисахариды, продуцируемые клетками хрящевой ткани, во внеклеточном матриксе. Эффективность адипогенной дифференцировки анализировали с помощью окрашивания клеток жировым красным O (Oil Red O), позволяющим выявить липидные включения в цитоплазме клеток. Ядра докрашивали гематоксилином.

При статистической обработке данных рассчитывали среднее арифметическое $(M)$ и его стандартную ошибку ( $\pm \mathrm{SEM})$. Достоверность различий оценивали по $t$-критерию Стьюдента при р $<0,05$.

Результаты. ММСК, выделенные из ЖТ как собак, так и кошек, обладали сильной адгезией и через 24 ч после выделения обнаруживались прикрепленными к поверхности дна культурального флакона, что согласуется с одним из минимальных критериев, которым должны соответствовать ММСК млекопитающих в культуре (2). На 4-е сут культивирования число клеток увеличивалось. Клетки, выделенные из ЖТ кошек и собак, имели схожие морфологические характеристики (рис. 1, А, Б). Полученные клеточные популяции представляли собой два типа клеток: мелкие

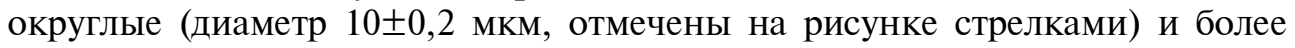

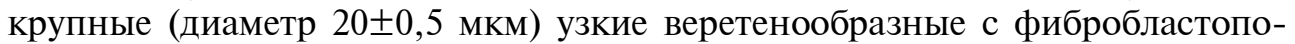
добной морфологией. Время одной цитогенерации у трех культур ММСК

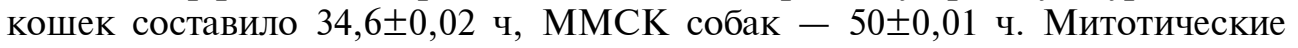
индексы ММСК кошек и ММСК собак составили соответственно 3,4 и 2,7 \%о (табл.). ММСК кошек образовывали монослой на 12-е сут культивирования (см. рис. 1, В) при посеве $1 \times 10^{4}$ клеток на $1 \mathrm{~cm}^{2}$, а ММСК собак при тех же условиях на 15-е сут (см. рис. 1, Г). Как видно из данных, представленных в таблице, эффективность клонообразования ММСК, выделенных из ЖТ кошек и собак, была высокой, что также подтверждает их 
принадлежность к ММСК.

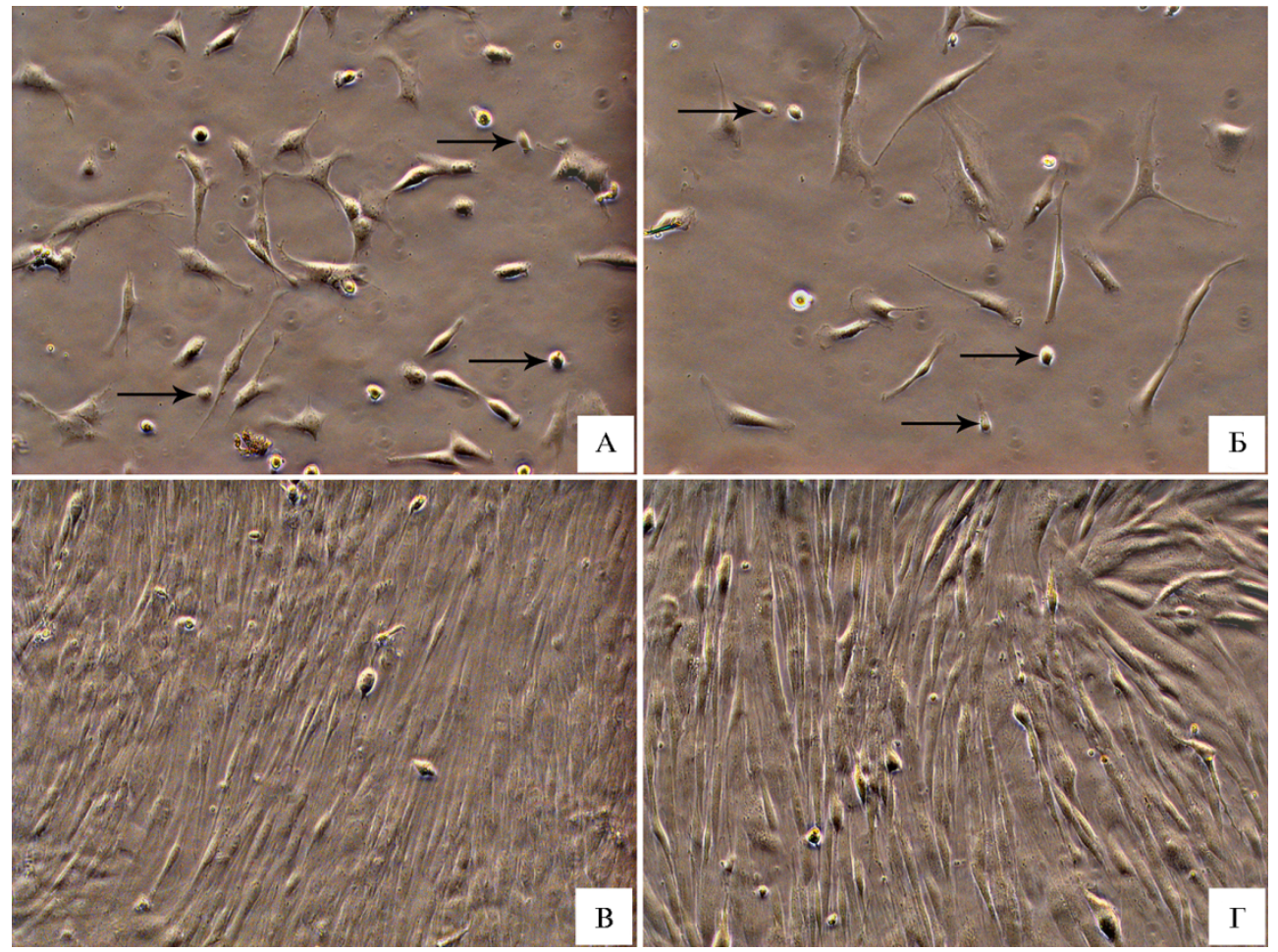

Рис. 1. Клетки с фенотипом мультипотентных мезенхимных стволовых клеток (ММСК) из жировой ткани мелких домашних животных на 4-е сут после выделения (А - ММСК кошки, Б - ММСК собаки); на 12-е сут (монослой) после выделения (В - ММСК кошки) и на 15-е сут (монослой) после выделения (Г - ММСК собаки). Стрелки указывают на мелкие округлые клетки. Нативный препарат, фазово-контрастная микроскопия (микроскоп Axio Observer D.1, «Carl Zeiss», Германия; увеличение ×200).

Свойства культур мультипотентных мезенхимных стволовых клеток (ММСК) in vitro, выделенных из жировой ткани кошек и собак $(M \pm \mathrm{SEM}, n=3)$

\begin{tabular}{c|c|c|c|c|c}
\hline $\begin{array}{l}\text { Культура } \\
\text { Клеток }\end{array}$ & Образец & $\begin{array}{c}\text { Метафазы/число } \\
\text { клеток }\end{array}$ & МИ, \%о & $\begin{array}{l}\text { Время цитоге- } \\
\text { нерации, ч }\end{array}$ & $\begin{array}{l}\text { Эффективность об- } \\
\text { разования клонов, \% }\end{array}$ \\
\hline ММСК кошки & 1 & $34 / 1000$ & 3,4 & $36,0 \pm 0,02$ & $89,0 \pm 0,22$ \\
& 2 & $33 / 1000$ & 3,3 & $33,0 \pm 0,04$ & $89,0 \pm 0,01$ \\
& 3 & $36 / 1000$ & 3,6 & $35,0 \pm 0,04$ & $87,0 \pm 0,07$ \\
ММСК собаки & 1 & $34,3 / 1000$ & 3,4 & $34,6 \pm 0,02$ & $88,3 \pm 0,10$ \\
& 2 & $28 / 1000$ & 2,8 & $50,0 \pm 0,01$ & $88,0 \pm 0,40$ \\
& 3 & $24 / 1000$ & 2,4 & $52,0 \pm 0,02$ & $87,0 \pm 0,01$ \\
& Среднее & $27,3 / 1000$ & 3,0 & $48,0 \pm 0,06$ & $89,0 \pm 0,05$ \\
& Седее & 2,7 & $50,0 \pm 0,01$ & $88,0 \pm 0,15$
\end{tabular}
из трех независимых экспериментов.

Ранее было показано, что ММСК, выделенные из ЖТ кошек (1821) и собак $(22,23)$, окрашиваются меченными флуорохромами антителами (AT) против антигенов (АГ) CD29 ( $\beta-1$ интегрин), CD44 (рецептор гиалуроновой кислоты), CD90 (Thy-1), CD105 (эндоглин), CD166 (ALCAM) и не окрашиваются АТ против АГ маркеров гемопоэтических клеток CD34 (сиаломуцин), CD45 (LCA - общий для лейкоцитов AГ) и CD73 (5'-терминальная нуклеотидаза). В нашем случае принадлежность полученных клеток к ММСК оценивали по их функциональным свойствам - способности формировать клетки жировой, костной и хрящевой тканей при индукции in vitro. После индукции в среде, содержащей адипогенные ростовые факторы, уже на 14-е сут наблюдали морфологические изменения в 

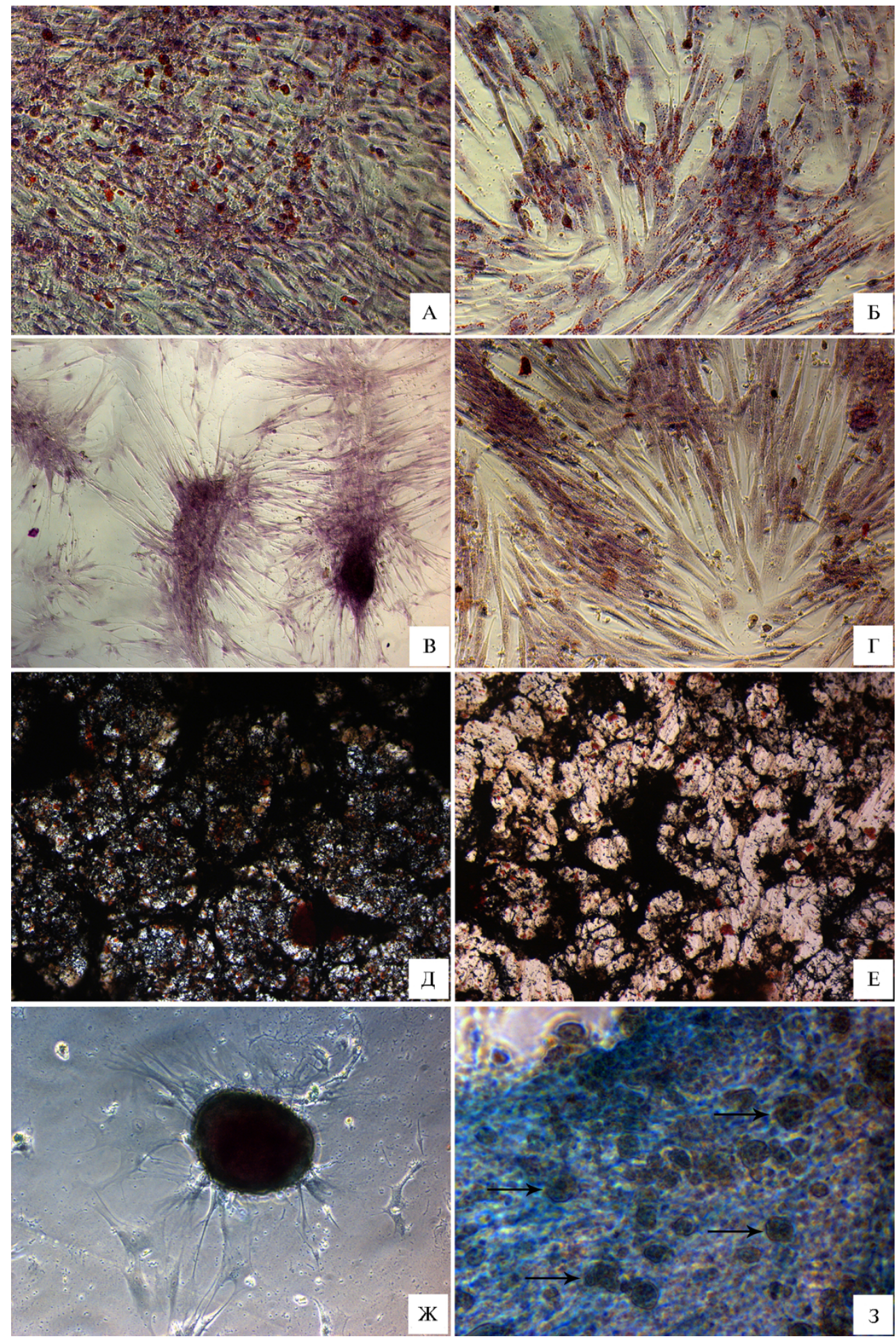

Рис. 2. Способность мультипотентных мезенхимных стволовых клеток (ММСК) из жировой ткани мелких домашних животных формировать клетки жировой, костной и хрящевой тканей при индукции: А, Б - соответственно ММСК кошек и собак на 21-е сут культивирования (окрашивание жировым красным О, адипогенная среда); В, Г - ММСК кошек и собак на 14-е сут культивирования (окрашивание на щелочную фосфатазу), Д, Е - то же на 21-е сут (серебрение по von Kossa) (остеогенная среда); Ж, 3 - ММСК кошек и собак на 21-е сут (окрашивание альциановым синим, хондрогенная среда). Стрелки указывают на изогенные группы, сходные по морфологии с лакунами гиалинового хряща. Фазово-контрастная микроскопия (микроскоп Ахіо Observer D.1, «Carl Zeiss», Германия), увеличение ×200 (А, Б, Г, Ж), ×100 (В, Д, Е) и ×630 (3). 
клетках, выделенных как из ЖТ кошки, так и из ЖТ собаки. Адиподифференцировка сопровождалась появлением клеток округлой формы с липидными везикулами в цитоплазме, которые выявлялись специфическим красителем жировым красным О (рис. 2, А, Б).

Известно, что существует прямая зависимость между наличием ЩФ в клетках и остеогенной дифференцировкой (16). Окрашивание ММСК ЖТ кошек и собак на специфическую активность эндогенной ЩФ оказалось положительным уже на 14-е сут культивирования в индукционной среде (см. рис. 2, В, Г). На 21-е сут после индукции с использованием сеpeбрения по von Kossa мы выявили наличие внеклеточного матрикса in vitro, на что указывало окрашивание фосфатов и карбонатов в черный цвет (см. рис. 2, Д, Е). Это свидетельствует о способности выделенных MМСК обоих видов к остеогенной дифференцировке in vitro.

После 21-суточного культивирования клеток в хондрогенной среде наблюдали формирование круглых структур, которые окрашивались альциановым синим (см. рис. 2, Ж). При созревании хондробласты начинают продуцировать межклеточный матрикс хрящевой ткани, содержащий мукополисахариды (24), которые этот краситель окрашивает в синий цвет. Различить клетки по морфологии в препаратах было сложно, однако визуализировались изогенные группы, схожие с лакунами гиалинового хряща (см. рис. 2, 3). Таким образом, ММСК, выделенные из внутренней ЖТ кошек и собак, при индукции к дифференцировке in vitro оказались способными образовывать клетки, подобные клеткам костной, жировой и хрящевой тканей. Полученные нами результаты согласуются с данными других исследователей (25-27). Сохранение в культуре функциональных способностей позволяют предположить, что ММСК кошек и собак могут быть перспективным материалом для лечения различных патологий костной и хрящевой тканей у мелких домашних животных. Полученные нами данные способствуют расширению знаний о поведении клеток в культуре, что позволит приблизиться к более глубокому пониманию процессов, происходящих с клетками-предшественниками в условиях in vitro.

Итак, мы получили культуры мультипотентных мезенхимных стволовых клеток (ММСК) из жировой ткани (ЖТ) кошек и собак. Для выделенных клеток характерны все главные признаки ММСК: сильная адгезия к пластиковой поверхности, высокая клонообразующая способность $(88,3 \pm 0,10 \%$ у ММСК кошек и $88,0 \pm 0,15 \%$ у ММСК собак), а также способность дифференцироваться по остео-, хондро- и адипогенному типу при химической индукции in vitro. Сравнительная характеристика ММСК кошек и собак выявила незначительные различия. Морфологические особенности культур клеток схожи, но при этом время одной цитогенерации ММСК у кошек составило $34,6 \pm 0,02$ ч, у собак - 50,0 $\pm 0,01$ ч, митотический индекс - соответственно 3,4 и 2,7 \%о, что свидетельствует о более высокой пролиферативной активности культур ММСК кошек. Полученные культуры клеток размножены и депонированы в Специализированной коллекции перевиваемых соматических клеточных культур сельскохозяйственных и промысловых животных при ВИЭВ им. Я.Р. Коваленко.

\footnotetext{
ФГБНУ ФНЦ Всероссийский НИИ экспериментальной ветеринарии им. Я.Р. Коваленко РАН, 109428 Россия, г. Москва, Рязанский пр., 24, корп. 1, e-mail: s-ip@mail.ru $₫$, s.vasileva89@yandex.ru, darya.korovina@gmail.com, viev@mail.ru, plych@mail.ru
}

Поступила в редакцию 


\title{
FROM FELINE AND CANINE ADIPOSE TISSUE
}

\author{
I.P. Savchenkova, S.A. Vasilyeva, D.G. Korovina, A.A. Shabeikin, A.M. Gulyukin
}

Federal Science Center Kovalenko All-Russian Research Institute of Experimental Veterinary RAS, 24/1, Ryazanskii pr., Moscow, 109428 Russia, e-mail s-ip@mail.ru ( $₫$ corresponding author), s.vasileva89@yandex.ru, darya.korovina@gmail.com, viev@mail.ru, plych@mail.ru

ORCID:

Savchenkova I.P. orcid.org/0000-0003-3560-5045

Vasilyeva S.A. orcid.org/0000-0001-5946-9071

Korovina D.G. orcid.org/0000-0003-2186-6084

Shabeikin A.A. orcid.org/0000-0003-3413-8131

The authors declare no conflict of interests

Acknowledgements:

The work was done according to project No. 0578-2018-0006 "Creation of new mammalian stem cell-based systems, including farm animals, with desired properties based on for veterinary medicine, virology and biotechnology"

Received December 13, 2018 doi: 10.15389/agrobiology.2019.2.395eng

\section{Abstract}

Multipotent mesenchymal stem cells (MMSCs) are a promising tool of regenerative medicine for treatment of various small animal diseases. MMSCs have a high proliferative activity, multipotent properties, low immunogenicity, as well as the ability to migrate to the damaged tissue and promote its healing and regeneration. Currently, the methods of regenerative medicine are actively developing to solve problems that are difficult to cope with alternative treatments. However, data on the use of these cells in the clinic are ahead of the study of the properties of these cells in culture. This paper is our first report on isolation cells with phenotype similar to mammalian multipotent mesenchymal stem cells from feline and canine adipose tissue. The aim of the presented research was to study the cells properties with a phenotype similar to MMSC isolated from feline and canine adipose tissue (AT) in vitro. Isolation of cells was achieved by mechanical and enzymatic treatments of the AT. For enzymatic dissociation, the tissues were treated with a $0.01 \%$ collagenase type II solution based on DMEM-LG (PanEco, Russia) with low glucose $(1 \mathrm{~g} / \mathrm{l})$ at $37{ }^{\circ} \mathrm{C}$ for $60 \mathrm{~min}$. The comparative analysis of properties of the derived cellular populations is carried out. Cells isolated from feline and canine adipose tissue had similar morphological characteristics and were represented by two cellular types: small round cells and larger narrow spindle like fibroblast. They had a strong adhesion to cultural plastic and high colonies formation ability, $88.3 \pm 0.10 \%$ for feline MMSCs and $88.0 \pm 0.15 \%$ for canine MMSCs. The generation time of feline MMSCs was $34.6 \pm 0.02 \mathrm{~h}$, while in canine MMSCs it was $50.0 \pm 0.01 \mathrm{~h}$. Mitotic index of feline and canine MMSCs was $3.4 \%$ and $2.7 \%$, respectively. The ability of the MMSCs to induced osteo-, chondro- and adipogenic differentiation in vitro was demonstrated using StemPro ${ }^{\circledR}$ Osteogenesis Differentiation Kit, StemPro ${ }^{\circledR}$ Chondrogenesis Differentiation Kit и StemPro® Adipogenesis Differentiation Kit (Gibco, USA), respectively. Adipogenic differentiation accompanied by the appearance of rounded cells with lipid vesicles in the cytoplasm that were identified with the specific dye Oil red O. Specific staining of feline and canine MMSCs for endogenous alkaline phosphatase was positive on day 14 of culture in the induction medium. MMSCs stained by von Kossa revealed extracellular matrix formation on day 21 after induction. Alcian blue staining of cells cultured in chondrogenic medium for 21 days visualized formation of round structures with isogenic groups similar to the lacunae of hyaline cartilage. Thus, it was shown that cells isolated from feline and canine adipose tissue exhibit in culture the properties of MMSC. The derived cell cultures were propagated and deposited to Kovalenko VIEV Specialized Collection of somatic cell cultures of farm and commercial animals.

Keywords: multipotent mesenchymal stem cells, adipose tissue, culture, induced differentiation in vitro, feline, canine.

\section{R E F E R E N C ES}

1. Murray I.R., West C.C., Hardy W.R., James A.W., Park T.S., Nguyen A., Tawonsawatruk T., Lazzari L., Soo C., Peault B. Natural history of mesenchymal stem cells, from vessel walls to culture vessels. Cell Mol. Life Sci., 2014, 71(8): 1353-1374 (doi: 10.1007/s00018-013-1462-6).

2. Dominici M., Le Blanc K., Mueller I., Slaper-Cortenbach I., Marini F., Krause D., Deans R., Keating A., Prockop Dj., Horwitz E. Minimal criteria for defining multipotent mesenchymal stromal cells. The International Society for Cellular Therapy position statement. Cytotherapy, 2006; 8(4): 315-317 (doi: 10.1080/14653240600855905).

3. Korovina D.G., Yurov K.P., Volkova I.M., Alekseenkova S.V., Vasil'eva S.A., Savchenkova E.A., Savchenkova I.P. Konevodstvo i konnyi sport, 2015, 6: 31-33 (in Russ.).

4. Volkova I.M., Viktorova E.V., Savchenkova I.P., Gulyukin M.I. Characteristic of mesenchymal stem cells, isolated from bone marrow and fatty tissue of cattle. Sel'skokhozyaistvennaya Biologiya [Agricultural Biology], 2012, 2: 32-38 (doi: 10.15389/agrobiology.2012.2.32eng).

5. Rogovaya O.C., Krasnov M.S., Kosovskaya E.V., Kosovskii G.Yu. Mesenchymal stem cells (MSC) as agents, reducing immunogenicity of the graft (review). Sel'skokhozyaistvennaya Biologiya [Agricultural Biology], 2011, 2: 15-20 (in Russ.). 
6. Sergeev M.A., Amirov D.R. Uchenye zapiski Kazanskoi gosudarstvennoi akademii veterinarnoi meditsiny im. N.E. Baumana, 2017, 230(2): 135-138 (in Russ.).

7. Chae H.K., Song W.J., Ahn J.O., Li Q., Lee B.Y., Kweon K., Park S.C., Youn H.Y. Immunomodulatory effects of soluble factors secreted by feline adipose tissue-derived mesenchymal stem cells. Vet. Immunol. Immunopathol., 2017, 191: 22-29 (doi: 10.1016/j.vetimm.2017.07.013).

8. Quimby J.M., Webb T.L., Randall E., Marolf A., Valdes-Martinez A., Dow S.W. Assessment of intravenous adipose-derived allogeneic mesenchymal stem cells for the treatment of feline chronic kidney disease: a randomized, placebo-controlled clinical trial in eight cats. J. Feline Med. Surg., 2016, 18(2): 165-171 (doi: 10.1177/1098612X15576980).

9. Parys M., Nelson N., Koehl K., Miller R., Kaneene J.B., Kruger J.M., Yuzbasiyan-Gurkan V. Safety of intraperitoneal injection of adipose tissue-derived autologous mesenchymal stem cells in cats. Journal of Veterinary Internal Medicine, 2016, 30(1): 157-163 (doi: doi: 10.1111/jvim.13655).

10. Nam A., Han S.M., Go D.M., Kim D.Y., Seo K.W., Youn H.Y. Long-term management with adipose tissue-derived mesenchymal stem cells and conventional treatment in a dog with hepatocutaneous syndrome. Journal of Veterinary Internal Medicine, 2017, 31(5): 1514-1559 (doi: 10.1111/jvim.14798).

11. Dehghan M.M., Eslaminejad M.B., Motallebizadeh N., Ashrafi Halan J., Tagiyar L., Soroori S., Nikmahzar A., Pedram M., Shahverdi A., Kazemi Mehrjerdi H., Izadi S. Transplantation of autologous bone marrow mesenchymal stem cells with platelet-rich plasma accelerate distraction osteogenesis in a canine model. Cell Journal, 2015, 17(2): 243-252 (doi: 10.22074/cellj.2015.3724).

12. Hoffman A.M., Dow S.W. Concise review: stem cell trials using companion animal disease models. Stem Cells, 2016, 34(7): 1709-1729 (doi: 10.1002/stem.2377).

13. Bertolo A., Steffen F., Malonzo-Marty C., Stoyanov J. Canine mesenchymal stem cell potential and the importance of dog breed: implication for cell-based therapies. Cell Transplant, 2015, 24(10): 1969-1980 (doi: 10.3727/096368914X685294).

14. Markoski M. Advances in the use of stem cells in veterinary medicine: from basic research to clinical practice. Scientifica (Cairo), 2016, 2016: Article ID 4516920 (doi: 10.1155/2016/4516920).

15. Savchenkova I.P., Ernst L.K., Gulyukin M.I., Viktorova E.V. Metodicheskie nastavleniya po vydeleniyu mul'tipotentnykh mezenkhimal'nykh stvolovykh kletok iz tkanei vzroslykh osobei mlekopitayushchikh, izucheniyu ikh svoistv i priznakov [Methodical instructions on the allocation of multipotent mesenchymal stem cells from the tissues of adult mammals, study of their properties and signs]. Moscow, 2010 (in Russ.).

16. Uzbekov R.E. Biokhimiya, 2004, 69(5): 597-611 (in Russ.).

17. Webb T.L., Quimby J.M., Dow S.W. In vitro comparison of feline bone marrow-derived and adipose tissue-derived mesenchymal stem cells. J. Feline Med. Surg., 2012, 14(2): 165-168 (doi: 10.1177/1098612X11429224).

18. Vieira N.M., Brandalise V., Zucconi E., Secco M., Strauss B.E., Zatz M. Isolation, characterization, and differentiation potential of canine adipose-derived stem cells. Cell Transplant, 2010 , 19(3): 279-289 (doi: 10.3727/096368909X481764).

19. Parys M., Nelson N., Koehl K., Miller R., Kaneene J.B., Kruger J.M., Yuzbasiyan-Gurkan V. Safety of intraperitoneal injection of adipose tissue-derived autologous mesenchymal stem cells in cats. Journal of Veterinary Internal Medicine, 2016, 30(1): 157-163 (doi: 10.1111/jvim.13655).

20. Webb T.L., Quimby J.M., Dow S.W. In vitro comparison of feline bone marrow-derived and adipose tissue-derived mesenchymal stem cells. J. Feline Med. Surg., 2012, 14(2): 165-168 (doi: 10.1177/1098612X11429224).

21. Kim H.R., Lee J., Byeon J.S., Gu N.Y., Lee J., Cho I.S., Cha S.H. Extensive characterization of feline intra-abdominal adipose-derived mesenchymal stem cells. Journal of Veterinary Science, 2017, 18(3): 299-306 (doi: 10.4142/jvs.2017.18.3.299).

22. Takemitsu H., Zhao D., Yamamoto I., Harada Y., Michishita M., Arai T. Comparison of bone marrow and adipose tissue-derived canine mesenchymal stem cells, BMC Veterinary Research, 2012, 8: 150 (doi: 10.1186/1746-6148-8-150).

23. Spencer N.D., Lopez M.J. In vitro adult canine adipose tissue-derived stromal cell growth characteristics. Methods Mol. Biol., 2011, 702: 47-60 (doi: 10.1007/978-1-61737-960-4_5).

24. Hoffman L.M., Weston A.D., Underhill T.M. Molecular mechanisms regulating chondroblast differentiation. The Journal of Bone \& Joint Surgery, 2003, 85(Suppl. 2): 124-132.

25. Neupane M., Chang C.C., Kiupel M., Yuzbasiyan-Gurkan V. Isolation and characterization of canine adipose-derived mesenchymal stem cells. Tissue Eng. Part. A, 2008, 14(6): 1007-1015 (doi: 10.1089/tea.2007.0207).

26. Requicha J.F., Viegas C.A., Albuquerque C.M., Azevedo J.M., Reis R.L., Gomes M.E. Effect of anatomical origin and cell passage number on the stemness and osteogenic differentiation potential of canine adipose-derived stem cells. Stem Cell Rev., 2012, 8(4): 1211-1222 (doi: 10.1007/s12015-012-9397-0).

27. Lee J., Lee K.S., Kim C.-L., Byeon J.S., Gu N.-Y., Cho I.-S., Cha S.-H. Effect of donor age on the proliferation and multipotency of canine adipose-derived mesenchymal stem cells. Journal of Veterinary Science, 2017, 18(2): 141-148 (doi: 10.4142/jvs.2017.18.2.141). 